find are a project of 1903 and an experimental engine said to have been tested before the War. Otherwise, the author appears to have drawn all his material from the German, British and American literature.

The level of the book is elementary; it is not, however, suitable for any class of students that I myself can think of, being too unsystematic and uneven in the amount of knowledge required for understanding. In any event, there are already several more satisfactory books on the market, written by authors having more immediate access to their sources. The translation is adequate, but some of the editorial work could be improved. To take a small, but typical, example, when the phrase "liquid propellant engines" is first introduced, "L.P.E." is carefully placed in parentheses after it as though this abbrevia. tion will be used in what follows; yet the full phrase is meticulously spelled out on every subsequent occasion. Another example appears at the end: a short list of references is followed by "suggestions for further reading", nearly half of these have just appeared in the reference list.

Translating and editing a technical book is, of course, a difficult and somewhat unrewarding task. In the present case it will have been made harder by the fact that the book was printed (not very well, it must be said) in Poland. What a pity, therefore, that this effort was not expended on a more worthy object. D. B. Spalding

\section{FROM STIRRUP TO CRANK}

Medieval Technology and Social Change

By Lynn White, jun. Pp. $194+12$ plates. (Oxford: The Clarendon Press, 1962.) $30 s$.

MN of the Renaissance like Francis Bacon were fond of reciting the list of recent discoveries which, in their eyes, marked the beginning of a new age: the sea-route to the East, the invention of printing, the navigator's compass, Columbus's voyage and the fury of gunpowder-these were taken to signify not merely Europe's inventiveness and daring nor her impressive command over Nature, but the possibility of an easier, richer, finer life. The Renaissance Utopia was founded on technological excellence. Broadly speaking this Renaissance view of history has remained in force almost to our own day, for if our vision of the future is less rosy we still for the most part (and rightly) trace the emergence of the characteristics of modern technology and modern society to the age of the Renaissance. Prof. White does not seek to challenge this view; rather it is his object to correct its perspective by pointing out that if the roots of modern technology first became conspicuous in the sixteenth and seventeenth centuries it was because the seed had germinated far earlier, and that even the profound impact of technology on society which is to us a truism (although the Renaissance scarcely suspected it) had begun long before the Renaissance occurred.

The plain fact is that if we care seriously to understand the development of our civilization (and Prof. White, who is a splendid historian, does have a deep concern for this) we cannot be satisfied by the glib talk of discovery and invention that flattered the self-esteem of the Renaissance. How did the compass, the making of paper or the use of wind-power (none of which was a European invention) make their way to Europe from the Far East? Moreover, why was their influence so much greater in the West than in the East? What technical considerations prompted the peculiar agricultural practice of Western Europe, neither Roman nor Barbarian in origin, which endured for more than a thousand years? For this agricultural system was, of course, in its turn the foundation for a social and political system of almost equal duration. What permitted the relative abundance and (as Prof. White adds) vitality of late medieval society, urging it to expand beyond the Danube and the Volga to both the
Indies ? Whence came the military strength to implement this expansion? Above all, why did the technical mutation towards the mechanization of production occur in Europe alone? Machines and tools were not unknown outside Europe: indeed, it is likely that in, say, the tenth century A.D. Europeans were inferior to the Chinese in mechanical skill. But it was in Europe alone that manufacture. agriculture, economy and society were ruthlessly cast into upheaval by machinery and its concomitant, power.

Prof. White is well aware, as a good humanist must be, that techniques are not a sufficient condition for historical drama; but they are a necessary condition. A vigorous. active population must command an adequate source of protein; an armoured, lance-wielding horseman must have his feet in stirrups; a thrusting economy must surpass the tempo of the ox. It is not hard-indeed, it is almost too easy-to imagine how the introduction of explosive artillery modified medieval warfare; yet this was a process that extended over more than two hundred years. It is very difficult to discern the obscure causes of the far more gradual effects that required even longer to manifest themselves. Consider the crank: antiquity possessed one device--a small millstone with a handle-that could have been rotated but, as Prof. White assures us, certainly was not. The first-known use of a crank (on a grindstone) was c. A.D. 825. The compound crank is not found until five hundred years later, and is not embodied in a carpenter's brace until a century after that (c. 1420). Then, during the full tide of the Renaissance, the crank figures in a host of mechanical devices, serving not merely as a handle but, in association with the connecting-rod, for the conversion of motion.

The history of medieval technology is the history of small things with great effects. The evidence is hard to recover and interpret. Only the practised and learned historian can realize the significance of the change in a technical term of a charter, or of some seemingly meaningless elements in an illumination. Only a shrewd guide can thread a plausible path through the multitude of mistranslations, repeated errors, and foolish guesses that bedevils this still infant subject. Prof. White is both. He is, indeed, one of the very few professional historians of medieval technology. Hitherto this branch of history has been cultivated, of necessity, by archæologists, art historians, textual crities and especially economic historians as an adjunct to their central interests. In this admirable book, which certainly owes much to these earlier studies, technology is the central interest. It has only two defects: it is too short, and too closely written. Let us hope that Prof. White will publish many more books drawing more expansively on his learning and good sense.

A. Rupert Hali

\section{FUNDAMENTALS OF MATHEMATICS}

\section{Fundamental Concepts of Mathematics}

By Prof. R, L. Goodstein. (International Series of Monographs on Pure and Applied Mathematics, Vol. 22.) Pp. viii +279 . (London and New York: Pergamon Press, 1962.) 40s. net.

A READY welcome may be given to this book. We A have all too fow of its kind at present. The title is explicit enough if one observes in the preface that the author has concentrated on themes which interest him, by no means forgetful of the fact that there are countless others which might equally well have been included. He is writing especially for the 'cultivated amateur', not for those in search of a technique. It is true that there is a dearth of mathematicians; what is slightly doubtful is whether recruits will be found other than by the hard way of the traditional struggle for manipulative mastery. That is, it would seem that these pages should be regarded as some. thing of a prize (as indeed they are) for those who have 